POIMEN : Jurnal Pastoral Konseling

ISSN (Print)

ISSN (Online)

http://ejournal-iakn-manado.ac.id/index.php/poimen

Vol.1, No.1, pp. 1 - 67, Juni 2020

\begin{tabular}{|c|c|}
\hline Diterima & 15 Mei 2020 \\
\hline Disetujui & 29 Juni 2020 \\
\hline
\end{tabular}

\title{
PERAN LAKI-LAKI DAN PEREMPUAN DALAM KEJADIAN 1-3 DAN IMPLIKASI TERHADAP PASTORAL DI GEREJA MASEHI INJILI DI MINAHASA JEMAAT YERUSALEM PAAL DUA MANADO.
}

\author{
Melissa MF Waturandang 1 \\ Dosen Psikologi di Institut Agama Kristen Negeri Manado, Email : melissawaturandang@gmail.com \\ Leonardo C. Dendeng \\ Institut Agama Kristen Negeri Manado, Email : leonardo_dendeng@iakn-manado.ac.id
}

\begin{abstract}
ABSTRAK
Tujuan dari penelitian ini adalah (1) menganalisis peran laki-laki dan perempuan dalam Kejadian 1-3, (2) mengidentifikasi dan menganalisis peran laki-laki dan perempuan dalam keluarga di Jemaat (3) menganalisis dan mendeskripsikan pastoral gereja tentang peran laki-laki dan perempuan dalam keluarga di Jemaat. Penelitian ini merupakan penelitian kualitatif, dengan analisis socio-historis untuk menganalisa teks Kejadian 1-3, di Gereja Masehi Injili di Minahasa (GMIM) Jemaat Yerusalem Paal Dua Manado pada tahun 2018.

Data dikumpulkan melalui tafsir, observasi, wawancara dan studi dokumentasi. Dari hasil analisis dan intepretasi data diperoleh indikasi bahwa: (1) peran laki-laki dan perempuan dalam Kejadian 1-3 tidak setara, dimana laki-laki masih lebih tinggi, sesuai dengan konteks pada masyarakat agraris pada waktu itu (2) peran laki-laki dan perempuan dalam keluarga walaupun sudah dalam konteks masyarakat jaringan tapi masih tidak setara, dimana laki-laki masih lebih tinggi seperti pada masyarakat agraris karena jemaat masih membaca Alkitab tanpa tahu konteks penulisan (3) Gereja masih belum melihat peran laki-laki dan perempuan yang setara sebagai sesuatu yang penting dalam pelayanan pastoral karena itu secara tidak langsung masih melestarikan pandangan patriakal seperti pada masyarakat agraris.

Dari hasil temuan tersebut maka direkomendasikan (1) jemaat membaca Alkitab sesuai dengan konteks karena walaupun pesan Firman Tuhan tetap sama tapi konteks dan pembaca berubah (2) Gereja dalam pelayanan pastoral disarankan mengajarkan jemaat membaca Alkitab sesuai dengan konteks, tidak terkekang dengan konteks pada saat penulisan Alkitab tapi mengajarkan Firman Tuhan yang membebaskan dan iman yang dinamis.
\end{abstract}

Kata Kunci : peran, laki-laki dan perempuan, keluarga, pastoral 
The purpose of this study is (1) analyzing the roles of men and women in Genesis 1-3, (2) identifying and analyzing the roles of men and women in the family in the Church (3) analyzing and describing the pastoral church about the role of men and women in the family of the Church. This research is a qualitative study, with a socio-historical analysis to analyze the text of Genesis 1-3, at the Evangelical Christian Church in Minahasa (GMIM) of the Jerusalem Paal Dua Church in Manado in 2018.

Data is collected through interpretation, observation, interview and documentation study. From the results of the analysis and interpretation of the data obtained an indication that: (1) the roles of men and women in Genesis 1-3 are not equal, where men are still higher, according to the context in the agrarian society at that time (2) the role of men men and women in the family even though it is in the context of a networked society but still unequal, where men are still higher as in an agrarian society because the congregation still reads the Bible without knowing the context of writing (3) the Church still has not seen the role of men and women who equivalent as something important in pastoral care because it indirectly still preserves patriarchal views as in agrarian societies.

From these findings it is recommended that (1) the congregation read the Bible according to the context because even though the message of the Word of God remains the same but the context and readers change (2) the church in pastoral ministry is advised to teach the congregation to read the Bible according to context, not to be constrained by the context at the time of writing The Bible but teaches the liberating Word of God and dynamic faith.

Keywords: roles, male and female, family, pastoral 


\section{A. PENDAHULUAN}

Perkembangan teknologi dan masyarakat begitu pesat saat ini. Manuel Castell menyebut abad ini sebagai abad informasi, karena itu masyarakat saat ini disebut sebagai masyarakat jaringan (network society). ${ }^{1}$ Masyarakat ini ditandai dengan saling terhubungannya anggota satu dengan lainnya dengan suatu telekomunikasi masa dan begitu cepatnya informasi dibagi (shared) dan dapat diakses dimana saja dengan mudah dengan gawai (gadget), dalam hal ini telepon pintar (smartphone) yang sudah merupakan barang wajib bagi setiap anggota masyarakat jaringan. Begitu pesatnya perkembangan teknologi dengan berbagai digitalisasi dan fusi teknologi yang ada sehingga disebut sebagai revolusi industri 4.0 oleh Klaus Schwab. ${ }^{2}$ Dalam hal pekerjaan masyarakat tidak lagi melihat pada jenis kelamin tapi dari skil dan kompetensi yang ada. Dalam hal ini emansipasi perempuan telah begitu maju dan sistem patriakal sudah mulai ditinggalkan. Sistem yang sebenarnya begitu berpengaruh dalam masyarakat agraris pada penulisan Alkitab Perjanjian Lama khususnya kitab Kejadian 1-3.

Kejadian 1-3 adalah bagian awal dari Alkitab Perjanjian Lama yang menceritakan tentang awal mula dunia. Secara khusus juga menceritakan bagaimana manusia pertama kali diciptakan dan juga peran-peran yang diberikan pada laki-laki dan perempuan. Peran laki-laki dan perempuan sepertinya bertentangan dalam Kejadian 1 dan Kejadian 2-3. Kejadian 1 sepertinya menggambarkan peran laki-laki dan perempuan setara karena diciptakan bersama-sama segambar dan serupa Tuhan.

Berfirmanlah Allah: "Baiklah Kita menjadikan manusia menurut gambar dan rupa Kita, supaya mereka berkuasa atas ikan-ikan di laut dan burung-burung di udara dan atas ternak dan atas seluruh bumi dan atas segala binatang melata yang merayap di bumi." Maka Allah menciptakan manusia itu menurut gambar-Nya, menurut gambar Allah diciptakan-Nya dia; laki-laki dan perempuan diciptakanNya mereka. Allah memberkati mereka, lalu Allah berfirman kepada mereka: "Beranakcuculah dan bertambah banyak; penuhilah bumi dan taklukkanlah itu, berkuasalah atas ikan-ikan di laut dan burung-burung di udara dan atas segala binatang yang merayap di bumi." (Kejadian 1:26-28,TB)

Kejadian 2 menggambarkan bahwa peran laki-laki dan perempuan tidak setara, dimana laki-laki lebih tinggi daripada perempuan. Karena laki-laki diciptakan lebih dulu daripada perempuan, bahkan perempuan diciptakan dari tulang rusuk laki-laki.

Dan dari rusuk yang diambil TUHAN Allah dari manusia itu, dibangun-Nyalah seorang perempuan, lalu dibawa-Nya kepada manusia itu. Lalu berkatalah manusia itu: "Inilah dia, tulang dari tulangku dan daging dari dagingku. Ia akan dinamai perempuan, sebab ia diambil dari laki-laki." (Kejadian 2:22-23, TB)

Pada Kejadian 3 malah lebih jelas lagi posisi laki-laki lebih tinggi dari perempuan. Setelah manusia laki-laki dan perempuan memakan buah dari pohon yang dilarang maka Tuhan mengutuk manusia. Kutukan ini menentukan posisi dan memberikan peran kepada manusia berdasarkan jenis kelamin.

Firman-Nya kepada perempuan itu: "Susah payahmu waktu mengandung akan Kubuat sangat banyak; dengan kesakitan engkau akan melahirkan anakmu; namun engkau akan berahi kepada suamimu dan ia akan berkuasa atasmu." Lalu firmanNya kepada manusia itu: "Karena engkau mendengarkan perkataan isterimu dan memakan dari buah pohon, yang telah Kuperintahkan kepadamu: Jangan makan dari padanya, maka terkutuklah tanah karena engkau; dengan bersusah payah engkau akan mencari rezekimu dari tanah seumur hidupmu: semak duri dan rumput duri yang akan dihasilkannya bagimu, dan tumbuh-tumbuhan di padang

${ }^{1}$ Manuel Castell, 2011, The Rise of Network Society, (Wiley-Blackwell)

${ }^{2}$ Klaus Schwab, 2016, The Fourth Industrial Revolution, (New York: Crown Business), 12 
akan menjadi makananmu; dengan berpeluh engkau akan mencari makananmu, sampai engkau kembali lagi menjadi tanah, karena dari situlah engkau diambil; sebab engkau debu dan engkau akan kembali menjadi debu." (Kejadian 3:16-19 TB)

Para ahli dengan teori Sumber menjelaskan bahwa perbedaan tentang kisah penciptaan laki-laki dan perempuan secara khusus peran laki-laki dan perempuan dalam Kejadian 1 dengan 2-3 adalah karena ditulis oleh penulis yang berbeda dengan tujuan dan konteks yang berbeda pula. Dalam teori ini Kejadian 1 (lebih tepatnya pasal 1-2:4a) adalah kisah dalam sumber P (Priestly) ditulis oleh para imam pada saat pembuangan di Babel. Kejadian 2-3 (lebih tepatnya pasal 2:4b-3:24) adalah kisah dalam sumber J (Yahwist) ditulis pada masa Kerajaan Israel masih bersatu pada masa Raja Daud pada sekitar tahun 1000 SM. Kedua konteks masyarakat pada saat penulisan ini adalah masyarakat agraris.

GMIM Jemaat Yerusalem Paal Dua yang hidup di tahun 2018 dalam masyarakat jaringan, masih melihat bahwa laki-laki lebih dominan dari perempuan. Dapat dilihat melalui observasi awal bahwa pada kotbah dan doa-doa yang disampaikan dalam ibadahibadah yang dipimpin oleh pelayan khusus bahwa laki-laki/suami adalah kepala rumah tangga dan imam dalam keluarga, sedangkan perempuan/istri adalah ibu rumah tangga. Peran publik adalah peran laki-laki sedangkan peran domestik adalah peran perempuan. Dalam wawancara awal ditanyakan kepada jemaat mengapa demikian, beberapa menjawab bahwa karena seperti demikian yang telah tertulis dalam Alkitab khususnya kitab Kejadian.

Gereja tentang peran laki-laki dan perempuan mempunyai tanggung jawab pastoral untuk mengajarkan kepada jemaat tentang bagaimana seharusnya peran laki-laki dan perempuan dalam keluarga. Gereja dalam pelayanan pastoral bukan hanya berdoa dan berkotbah saja tapi membentuk perilaku berdasarkan Firman Tuhan yang membebaskan dan memerdekakan. Gereja seharusnya mengajarkan iman yang dinamis dalam menggembalakan domba-domba yang terus berkembangan dan berubah sesuai dengan perkembangan zaman dan konteks.

Dengan begitu pesatnya perkembangan teknologi, sehingga masyarakat pada tahun 2018 disebut sebagai masyarakat jaringan, jemaat GMIM Yerusalem masih memertahankan pola pikir dan tingkah laku seperti pada masyarakat agraris khususnya berkaitan dengan peran laki-laki dan perempuan dalam keluarga. Karena itu menarik untuk mengkaji bagaimana peran laki-laki dan perempuan dalam Kejadian 1-3, bagaimana peran laki-laki dan perempuan dalam keluarga di Jemaat dan bagaimana pastoral gereja terhadap peran laki-laki dan perempuan dalam keluarga di GMIM Yerusalem Paal Dua Manado.

\section{B. DESKRIPSI TEORETIK}

\section{Analisis Socio-Historis Kejadian 1-3}

Kejadian 1 sebenarnya tidak bermaksud untuk menceritakan penciptaan secara faktual. Konteks penulisan kejadian 1 oleh para imam pada saat pembuangan di Babel, kisah yang termuat dalam sumber $\mathrm{P}$ ini, sebenarnya adalah sebagai identitas dari bangsa Israel yang dibuang, jauh dari tanah airnya. Pada saat itu telah banyak kisah-kisah penciptaan dunia seperti kisah dari Babel. Bangsa Israel perlu ada identitas bagaimana mereka bisa ada sebagaimana mereka ada saat ini. Kisah penciptaan dalam Kejadian 1 mau menunjukkan bahwa ada keteraturan dari alam. Semuanya baik dan sudah ada tempatanya. Penciptaan laki-laki dan perempuan tidak dimaksudkan bahwa peran lakilaki dan perempuan sama, karena konteks pada saat itu posisi laki-laki lebih dominan daripada perempuan, dikenal sebagai sistem patriakal. Dalam Kejadian 1 seolah-olah setara, tapi pada bagian lainnya kisah sumber $\mathrm{P}$ yakni dalam kitab Imamat, maka terlihat 
bahwa apa yang diciptakan baik, termasuk laki-laki dan perempuan yang segambar dan serupa Tuhan, ternyata ada kekurangannya yaitu perempuan karena perempuan menggeluarkan darah pada saat datang bulan sehingga menjadi tidak bersih. Dalam Kejadian 1 tidak disebutkan mengenai posisi dan peran karena bukan ini tujuan dari kisah penciptaan itu. Sistem patriakal ini begitu terlihat dalam kitab Imamat. Semua ini merupakan sistem yang berlaku pada masyarakat agraris.

Kejadian 3 yang sebenarnya ditulis lebih awal dari Kejadian 1 diletakkan lebih kemudian dalam kitab Kejadian karena Kejadian 1 menceritakan kisah penciptaan dunia yang lebih umum, sangat jelas menunjukkan posisi dan peran dari laki-laki dan perempuan. Posisi dan peran ini bahkan diceritakan dalam cerita yang bergaya mitos untuk menjelaskan bagaimana posisi dan peran laki-laki menjadi lebih superior daripada perempuan. Kisah yang sebenarnya tidak masuk akal lagi bagi masyarakat jaringan. Kisah dalam Kejadian 2-3 begitu jelas menggambarkan bagaimana masyarakat agaris pada saat itu, yakni berkaitan dengan tanah. Manusia pertama yang ciptakan diterjemahkan oleh Alkitab Terjemahan Baru LAI sebagai 'manusia' dalam bahasa Ibrani adalah berasal dari kata Adam. Adam dari adama berarti tanah. Setelah laki-laki maka kemudian diciptakanlah perempuan melalui tulung rusuk laki-laki, dimana perempuan diambil dari laki-laki. Sangat jelas implikasi dari sistem patriakal disini karena laki-laki diciptakan terlebih dahulu maka laki-laki adalah yang lebih tua karena itu adalah pemimpin.

Kisah selanjutnya dalam Kejadian 3 menunjukkan posisi dan peran yang sangat jelas, yakni kisah di taman Eden tentang ular yang mempunyai kaki dan bisa berbicara, dan pohon yang tidak boleh dimakan buahnya. Setelah melanggar perintah Tuhan dengan memakan buah dari pohon yang tidak boleh dimakan buahnya maka posisi perempuan menjadi sangat jelas inferior. Perempuan harus melaksanakan kutukan ; susah payah mengandung, kesakitan melahirkan, berahi kepada suami dan di bawah kuasa lakilaki/suami. Posisi dan peran yang inferior sehingga perempuan dibatasi hanya pada peran domestik. Laki-laki bersusah payah mencari rejeki dari tanah, dengan berpeluh mencari makanan, sampai kemudian mati dan menjadi tanah. Pekerjaan yang dominan saat itu pada masyarakat agraris yakni bertani.

Kisah ini mengesahkan bahwa kutukan laki-laki adalah pemimpin dan pekerja, sedangkan perempuan di rumah saja untuk melaksanakan kutukan perempuan. Kisah ini menggambarkan sekaligus menglegalisasi sistem patriakal yang telah ada dalam masyarakat agraris Israel pada waktu itu. Patriakal adalah sebuah sistem sosial yang menempatkan laki-laki sebagai pemegang kekuasaan utama dan mendominasi dalam peran kepemimpinan politik, otoritas moral, hak social dan penguasaan property. ${ }^{3}$ Dalam domain keluarga, sosok yang disebut ayah memiliki otoritas terhadap perempuan, anakanak dan harta benda. Beberapa masyarakat patriakal juga patrineal yang berarti bahwa property dan gelar diwariskan kepada keturunan laki-laki. Secara tersirat sistem ini melembagakan pemerintahan dan hak istimewa laki-laki serta menempatkan posisi perempuan di bawah laki-laki. Sistem sosial patriaki menjadikan laki-laki memiliki hak istimewa terhadap perempuan. Dominasi mereka tidak hanya mencakup ranah personal saja, melainkan juga dalam ranah yang lebih luas seperti partisipasi politik, pendidikan, ekonomi, sosial, hukum dan lain-lain. Dalam ranah personal, budaya patriaki adalah akar munculnya berbagai kekerasan yang dialamatkan oleh laki-laki kepada perempuan. Atas dasar hak istimewa yang dimiliki laki-laki, mereka juga merasa memiliki hak untuk mengeksploitasi tubuh perempuan. ${ }^{4}$

Cerita dalam Kejadian 3 bergaya mitos tapi pesannya bagi masyarakat jaringan yang ada di tahun 2018 sangat jelas bahwa manusia tidak akan pernah menjadi Tuhan,

\footnotetext{
${ }^{3}$ Charles Bressler, 2007

${ }^{4}$ Nandika Guamawarti, 2009
} 
karena manusia adalah manusia. Dengan demikian menjadi jelas bahwa baik Kejadian 1 dan 2-3 menggambarkan bahwa posisi yang tidak setara antara laki-laki dan perempuan, dimana posisi laki-laki lebih superior daripada perempuan. Peran dan posisi dari laki-laki dan perempuan pada masyarakat agraris.

\section{METODOLOGI}

\section{Peran Laki-laki dan Perempuan dalam Keluarga di Jemaat}

Lokasi penelitian ini adalah di GMIM Yerusalem Paal Dua Manado yang terletak di Jalan Yos Sudarso, Kairagi Weru, Paal Dua, Kota Manado, Sulawesi Utara, Indonesia. Jemaat terdiri dari lima Kolom dan memiliki kurang lebih 101 Keluarga dan 413 jiwa. Mayoritas pekerjaan jemaat adalah Wirausaha dan Tukang. Pada umumnya jemaat berasal dari Minahasa.

Di Minahasa Perempuan Minahasa dipanggil Wewene. ${ }^{5}$ Dalam kebudayaan Minahasa, perempuan memiliki status yang unik. Mitologi Minahasa menceritakan bahwa manusia atau leluhur pertama yang ada di tanah Minahasa adalah Lumimuut. Lumimuut adalah seorang perempuan. Pria pertama lahir dari Lumimuut bernama Toar. Mitologi tersebut juga menjelaskan bahwa yang menciptakan Lumimuut adalah seorang dewi yang bernama Karema. Begitu pula dengan sejarah Minahasa dalam perspektif mitologis sangatlah feminis. Nama Pingkan untuk seorang perempuan Minahasa adalah simbol kekuatan, keberanian, dan kesetiaan. dalam mitologi disebutkan bahwa Pingkan berani melawan keinginan seorang raja yang ingin memperistrinya dan tetap setia pada suaminya Matindas. ${ }^{6}$ Cerita tentang Pingkan dan Matindas dulunya menjadi semacam cerita yang wajib diceritakan di acara-acara pernikahan sebagai teladan bagaimana menjadi sepasang suami istri yang ideal. Dalam hal kerja produktif pun wanita dan pria bekerjasama menggarap ladang dan hal ini ada dalam tradisi mapalus. Tokoh-tokoh perempuan Minahasa selanjutnya begitu maju sebut saja Maria Walanda Maramis tokoh yang diberikan gelar Pahlawan Nasional karena memerjuangkan pendidikan dan hak-hak perempuan yang bukan hanya sebatas pekerjaan domestik.

Dalam pengamatan yang peneliti lakukan di Jemaat GMIM Yerusalem Paal Dua, perempuan (istri) memang pada umumnya melakukan pekerjaan-pekerjaan domestik (mencuci piring, mencuci pakaian, memasak, mengurus anak dan pekerjaan rumah tangga lainnya). Hal tersebut nampak mulai dari pagi sampai sore bahkan malam, sebagian besar para suami belum berada di rumah, hanya para istri yang terlihat berada di rumah sambil melakukan pekerjaan-pekerjaan rumah tangga. Setelah beberapa kali peneliti melakukan pengamatan, sesuai dengan apa yang peneliti lihat dan dengar bahwa adanya kekerasan yang terjadi dari suami terhadap istri di beberapa keluarga, suami yang merasa memiliki kekuasaan penuh atas istri dan istri yang merasa dirinya ada di bawah suami. Adapun sebagian kecil laki-laki yang sebagai suami berada di rumah saat peneliti melakukan observasi pada pagi sampai malam hari sedangkan perempuan yang sebagai istri berada di rumah saat sore atau malam hari. Dalam setiap doa pada ibadah-ibadah yang dilakukan, terdengar doa bagi bapak sebagai kepala keluarga yang mengatur dan memenuhi kebutuhan keluarga, sedangkan istri sebagai ibu rumah tangga yang mendidik anak dan mengurus suami.

${ }^{5}$ Sita van Bemmelen,. 1987. "The Marriage of Minahasa Women in the period 1861-1933, Views and Changes". di dalam Elsbeth Locher-Scholten dan Anke Niehoff (eds.). Indonesian Women and Focus (Dordrecht: Foris Publication) hlm. 181-204

${ }^{6}$ W., Wolters, O. (1999). History, culture, and region in Southeast Asian perspectives (edisi ke-Rev. ed). Ithaca, N.Y.: Southeast Asia Program Publications, Southeast Asia Program, Cornell University. ISBN 9812300287. OCLC 41357331. 
Berdasarkan wawancara terhadap beberapa jemaat tentang pengertian laki-laki dan perempuan, jemaat mengatakan bahwa laki-laki dan perempuan jelas berbeda. Laki-laki diciptakan terlebih dahulu daripada perempuan dan perempuan diciptakan untuk mendampingi laki-laki. ${ }^{7}$ Dini jemaat mendasarkan pemahamannya berdasarkan Kejadian 2. Pekerjaan adalah tanggung jawab yang diberikan oleh Tuhan kepada manusia sebagai ciptaan Tuhan untuk mengolah bumi beserta isinya karena itu perlu dilakukan dengan penuh tanggung jawab. ${ }^{8}$ Disini jemaat mendasarkan pemahaman tentang pekerjaan berdasarkan Kejadian 1. Pekerjaan adalah bagian dari kehidupan manusia karena itu manusia harus mencari nafkah untuk hidup mereka. Laki-laki harus memiliki peran yang lebih tinggi dari perempuan karena laki-laki adalah sosok kepala keluarga yang seharusnya menjadi tulang punggung keluarga dalam mencari nafkah. ${ }^{9}$ Jemaat beranggapan bahwa tidak ada salahnya perempuan bekerja di luar rumah, akan tetapi seharusnya perempuan fokus pada pekerjaan rumah tangga. ${ }^{10}$ Pada zaman sekarang tidak dapat di pungkiri bahwa sudah banyak perempuan bekerja di luar rumah, akan tetapi dalam keluarga laki-laki harus tetap menjadi kepala keluarga dan perempuan sebagai ibu rumah tangga, karena pada nama keluarga selalu diawali dengan marga dari laki-laki baru perempuan. ${ }^{11}$ Jemaat lainnya menganggap peran kerja laki-laki dan perempuan dalam keluarga disesuaikan dengan keadaan, kalau keadaan dalam keluarga memungkinkan lakilaki yang bekerja mencari nafkah tentu saja harus dilakukan, tetapi kalau keadaan memungkinkan bahwa perempuan yang harus bekerja mencari nafkah harus dilakukan juga. $^{12}$ -

Laki-laki sebagai suami memang sudah seharusnya lebih hebat dari pada perempuan atau istri. Menurut jemaat ini dikarenakan laki-laki memiliki kekuatan secara fisik yang lebih kuat dari perempuan. ${ }^{13}$ Menurut wawancara lainnya dengan jemaat ${ }^{14}$ karena laki-laki adalah kepala keluarga yang tentunya mengatur setiap peraturan dalam keluarga. Laki-laki mempunyai banyak aspek yang lebih hebat dari perempuan, akan tetapi ada juga dari beberapa aspek perempuan yang lebih hebat dari laki-laki, misalnya dalam kepintaran intelektual, karena pada zaman sekarang perempuan lebih pintar dari laki-laki, akan tetapi secara tenaga (fisik) laki-laki memang lebih hebat dari pada perempuan. Laki-laki sebagai suami jika merasa lebih hebat dari perempuan itu wajarwajar saja, karena mereka adalah kepala keluarga, tetapi jangan karena merasa lebih hebat sehingga memperlakukan perempuan seenaknya. ${ }^{15}$

Jemaat GMIM Yerusalem Paal Dua Manado sebagian besar laki-laki menjadi pekerja di ranah publik dan perempuan sebagai ibu rumah tangga. Perempuan bisa saja bekerja di ranah publik tetapi tidak boleh meninggalkan tanggung jawabnya sebagai ibu rumah tangga yang harus dilaksanakan seratus persen. ${ }^{16}$ Ada karena laki-laki merasa dia yang bekerja dan bersusah payah mencari nafkah maka seringkali melakukan kekerasan fisik terhadap perempuan jika tidak memenuhi keinginanya di rumah, seperti makanan yang tidak sesuai dengan seleranya dan hal-hal lainnya, tetapi ada juga yang merasa lakilaki adalah penguasa, karena dia merasa memiliki kuasa atas perempuan (istrinya), maka dia tidak memiliki pekerjaan atau tidak bekerja untuk memenuhi kebutuhan keluarga, melainkan perempuan yang adalah istrinyalah yang bekerja untuk itu. ${ }^{17}$ Perempuan memiliki banyak potensi dalam menjadi seorang seorang pemimpin, tetapi secara struktur kepemimpinan laki-laki yang memimpin, contohnya ada di kolom tiga, bahwa penatua

\footnotetext{
${ }^{7}$ Wawancara dengan C.L. dan H.M.

${ }^{8}$ Wawancara dengan H.M.

${ }^{9}$ Wawancara dengan C.L.

${ }^{10}$ Wawancara dengan P.P.

${ }^{11}$ Wawancara dengan H.M.

${ }^{12}$ Wawancara dengan Y.L.

${ }^{13}$ Wawancara dengan H.M.

${ }^{14}$ Wawancara dengan P.P.

${ }^{15}$ Wawancara dengan Y.L.

${ }^{16}$ Wawancara dengan C.M.

${ }^{17}$ Wawancara dengan Y.L.
} 
dan syamas adalah seorang laki-laki. Kalau dalam keluarga, seharusnya memang laki-laki yang bekerja di ranah publik dan pekerjaan rumah tangga memang menjadi tanggung jawab dari perempuan. ${ }^{18}$

Di Jemaat GMIM Yerusalem Paal Dua Manado pembedaan antara laki-laki dan perempuan masih sangat nampak, masih ada anggota jemaat yang membudayakan budaya patriakal. Karena sebagian anggota jemaat berpegang pada pemahaman bahwa laki-laki yang diciptakan terlebih dahulu dari pada perempuan, perempuan diciptakan setelah lakilaki dan tentunya perempuan harus tunduk terhadap laki-laki. Ini menyebabkan kekerasan dalam rumah tangga (dari suami terhadap istri) terjadi, laki-laki yang selalu diutamakan untuk menjadi seorang pemimpin, perempuan tidak diperbolehkan untuk berkarir di ranah publik, dapat dilihat dalam struktur organisasi jemaat laki-laki yang lebih banyak menjadi seorang pemimpin. Dalam data pekerjaan anggota jemaat, dapat dilihat bahwa laki-laki yang lebih banyak bekerja di ranah publik dan perempuan sebagian besar hanya ada di ranah domestik. Hal ini di Indonesia memang didukung oleh peraturan perundangundangan yakni Undang-undang Nomor 12 tahun 1974 tentang Perkawinan pasal 34, dimana tugas istri mengatur urusan rumah tangga.

Sistem patriakal tidak lagi seharusnya sangat diutamakan pada zaman sekarang ini sekalipun masih banyak yang tetap memegang teguh sistem ini. Di Minahasa banyak tokoh-tokoh perempuan yang berkarir dan maju bahkan memperjuangkan hak perempuan seperti Maria Walanda Maramis, sehingga perempuan dapat diperhitungkan dalam status sosial. Oleh karena itu zaman sekarang pada masyarakat jaringan tidak sedikit perempuan yang mulai berkarir di ranah publik bersamaan dengan laki-laki, sehingga posisi dalam keluarga antara suami dan istri tidak lagi ada pembatasan dalam hal peran kerja. Keduanya dapat sama-sama bekerja di ranah publik pun melakukan pekerjaan domestik tergantung dengan kesepakatan bersama sebagai suami dan istri, sehingga tidak ada yang merasa sebagai superior pun inferior. Jemaat GMIM Yerusalem Paal Dua adalah masyarakat yang hidup pada tahun 2018 dalam konteks masyarakat jaringan masih berpikir dan bertindak seperti masyarakat pada zaman agraris, dengan masih sangat mendasarkan pemikiran dan tindakan pada budaya patriakal. Ini terjadi karena jemaat masih membaca Alkitab secara harafiah tanpa mengetahui konteks dan maksud penulisan dari Kejadian 13. Peraturan perundang-undangan juga memang mendukung untuk hal-hal seperti ini terus terjadi. Walaupun memang dalam observasi dan wawancara tidak ada jemaat yang menyinggung tentang aturan ini, peraturan ini memang sudah saatnya untuk diamandemen karena tidak sesuai dengan konteks masyarakat dan jemaat pada saat ini.

\section{HASIL DAN PEMBAHASAN}

\section{Peran Pastoral Gereja}

Pelayanan pastoral atau penggembalaan adalah pelayanan yang luas. Pelayanan pastoral adalah analogi dari bagaimana Tuhan menjaga jemaatnya seperti gembala terhadap domba. Hal ini dapat dilihat pada Mazmur 23 bagaimana Tuhan menjaga Daud. Yesus sendiri menganalogikan diriNya sebagai Gembala yang Baik, sedangkan manusia sebagai domba-dombanya (Yohanes 10). Karena sama seperti gembala menggembalakan dombanya maka pastoral ini mencakup banyak pelayanan seperti perkunjungan, kotbah, doa, dan pendampingan. Gembala dalam hal ini tidak hanya pada pelayanan ibadah tapi pada pendidikan iman yang nampak pada pola pikir dan tindakan.

Gereja belum melihat tentang peran dari laki-laki dan perempuan dalam keluarga sebagai sesuatu yang penting dalam hal kesetaraan karena itu tidak begitu menekankan ini

${ }^{18}$ Wawancara dengan I.L. 
dalam pelayanan pastoral. Dengan demikian gereja secara tidak langsung melestarikan pemahaman tentang peran laki-laki dan perempuan yang tidak setara. Kotbah-kotbah khususnya terkait peran laki-laki dan perempuan oleh pelayan khusus (penatua dana syamas) dan juga jemaat, masih menafsir secara harafiah sehingga peran laki-laki dan perempuan pada Kejadian khususnya pasal 2-3 masih dipegang dengan teguh oleh jemaat. Hal-hal seperti ini sebaiknya tidak dibiarkan oleh pendeta sebagai gembala dalam gereja. Pendeta haruslah mengajarkan para pelayan khusus untuk menyampaikan kotbah dengan tafsiran yang sesuai dengan konteks, secara khusus konteks penulisan dari kitab Kejadian.

Peran pastoral gereja sebagai gembala adalah menggembalakan domba-domba menuju jalan yang benar. Kotbah bukan cuman sekedar kata-kata dalam ibadah tapi akan memengaruhi perilaku. karena itu Firman Tuhan yang disampaikan dalam kotbah dan doa adalah Firman Tuhan yang membebaskan dan memerdekan dan iman yang dinamis dalam menggembalakan domba-domba yang terus berkembang sesuai dengan zaman dan konteks. Gereja yang mengajarkan atau membiarkan ketidaksetaraan antara peran lakilaki dan perempuan dalam jemaat maka tidak membaca Alkitab dan memahami konteks dari teks itu sendiri. Gereja sebagai gembala haruslah membaca Alkitab sesuai dengan konteks kemudian membimbing dombanya untuk mengikuti jalan yang sama. Hal-hal ketidaksetaraan peran laki-laki dan perempuan dalam keluarga jika disampaikan berulangulang dalam berbagai kesempatan seperti ibadah, kotbah dan doa walaupun tidak tepat dan tidak sesuai dengan konteks yang ada saat ini, akan seolah-olah menjadi benar karena sesuatu yang diulang-ulang akan dianggap sebagai sesuatu yang benar karena masuk dalam alam bawah sadar menurut teori psikoanalisa.

\section{E. PENUTUP}

Peran laki-laki dan perempuan dalam Kejadian 1-3 tidak setara, dimana laki-laki masih lebih tinggi, sesuai dengan konteks pada masyarakat agraris pada waktu itu. Peran laki-laki dan perempuan dalam keluarga walaupun sudah dalam konteks masyarakat jaringan tapi masih tidak setara, dimana laki-laki masih lebih tinggi seperti pada masyarakat agraris karena jemaat masih membaca Alkitab tanpa tahu konteks penulisan. Gereja masih belum melihat peran laki-laki dan perempuan yang setara sebagai sesuatu yang penting dalam pelayanan pastoral karena itu secara tidak langsung masih melestarikan pandangan patriakal seperti pada masyarakat agraris.

Dari hasil temuan tersebut maka direkomendasikan. Pertama, jemaat membaca Alkitab sesuai dengan konteks karena walaupun pesan Firman Tuhan tetap sama tapi konteks dan pembaca berubah. Kedua, gereja dalam pelayanan pastoral disarankan mengajarkan jemaat membaca Alkitab sesuai dengan konteks, tidak terkekang dengan konteks pada saat penulisan Alkitab tapi mengajarkan Firman Tuhan yang membebaskan dan iman yang dinamis. 


\section{DAFTAR PUSTAKA}

Alkitab Terjemahan Baru, Lembaga Alkitab Indonesia,

Bemmelen, Sita van. 1987. "The Marriage of Minahasa Women in the period 1861-1933, Views and Changes". di dalam Elsbeth Locher-Scholten dan Anke Niehoff (eds.). Indonesian Women and Focus (Dordrecht: Foris Publication) hlm. 181-204

Castell, Manuel, 2011, The Rise of Network Society, Wiley-Blackwell,

Coote, Robert B. and Ord, David Robert, 1991, In the Beginning : Creation and Priestly History, Minneapolis : Fortress Press

1989, The Bible's First History: From Eden to the Court David with the Yahwist, Minneapolis : Fortress Press

Coote, Robert B., dan Coote, Mary P., 2001, Kuasa Politik dan Proses Pembuatan Alkitab, Jakarta: BPK Gunung Mulia,

Gottwald, Norman K., 1987, The Hebrew Bible : A Socio-Literary Introduction, Minneapolis : Fortress Press

Graafland, 1983 [1888]. "Kaum Perempuan di Minahasa" [Terjadi dalam Maria Ulfah Subadio dan T. O. Ihromi (Eds.). Peranan dan Kedudukan Perempuan Indonesia (Yogyakarta: UGM Press) hlm. 36-46

K. H. E. "Perkawinan di Minahasa". di dalam Maria Ulfah Subadio dan T. O. Ihromi (Eds.). Peranan dan Kedudukan Perempuan Indonesia (Yogyakarta: UGM Press. 1983 [1894]) hlm. 170-178

Krisetya, Mesach, 2015, Bela Rasa yang Dibagirasakan, Jakarta : Duta Ministri

Makkelo, Ilham Daeng, 2010, Kota Seribu Gereja : Dinamika Keagamaan dan Penggunaan Ruang di Kota Manado, Yogyakarta : Ombak

Manoppo-Watupongoh, G. Y. J. 1989. "Perempuan Minahasa”. di dalam Journal Research and Development Sam Ratulangi University. Edisi Introductory Januari (Manado: Puslit Unsrat, 1989) hlm. 34-45

Melalatoa, M. Junus (1995-01-01). Ensiklopedi Suku Bangsa di Indonesia Jilid L-Z. Direktorat Jenderal Kebudayaan.

"Perempuan : Budaya Patriarki dan Kesetaraan Gender|UNJKita.com". UNJKita.com (dalam bahasa Inggris). 2016-04-11. Diakses tanggal 2017-11-30.

"Perempuan Dan Belenggu Peran Kultural". Jurnal Perempuan. Diakses tanggal 201711-30.

Ryken, Leland, 2011, Kamus Gambaran Alkitab The Dictionary of Biblical Imagery, Surabaya: Momentum

Schwab, Klaus, 2016, The Fourth Industrial Revolution, New York : Crown Business

"Sistem Kekerabatan Orang Minahasa - WACANA". www.wacana.co (dalam bahasa Inggris). Diakses tanggal 2017-11-30.

Stotth, Jhon, Isu-isu Global: Penilaian Masalah Sosial dan Moral Kontemporer Menurut Perspektif Kristen, Jakarta: Yayasan Komunikasi Bina Kristen

W., Wolters, O. (1999). History, culture, and region in Southeast Asian perspectives (edisi ke-Rev. ed). Ithaca, N.Y.: Southeast Asia Program Publications, Southeast Asia Program, Cornell University. ISBN 9812300287 . OCLC 41357331. 